Mumcu, A., Aras, M. (2021). "The Mediating Role of The Interactional Justice on The Effect of Mushroom Management on Organizational Cynicism" , Eskişehir Osmangazi Üniversitesi iiBF Dergisi, 16(2) , 300 - 316.

Doi: 10.17153/oguiibf.871101

Başvuru: 30.01.2021 Kabul: 3.04.2021

Araştırma Makalesi/Research Article

\title{
The Mediating Role of the Interactional Justice on the Effect of Mushroom Management on Organizational Cynicism
}

\begin{tabular}{|c|c|}
\hline $\begin{array}{l}\text { Mantar Yönetim Yaklaşımının Örgütsel Sinizm } \\
\text { Üzerindeki Etkisinde Etkileşim Adaletinin Aracılık Rolü }\end{array}$ & $\begin{array}{l}\text { The Mediating Role of the Interactional Justice on the } \\
\text { Effect of Mushroom Management on Organizational } \\
\text { Cynicism }\end{array}$ \\
\hline Öz & Abstract \\
\hline $\begin{array}{l}\text { Çalışma, mantar yönetimi tarzının örgütsel sinizm } \\
\text { üzerindeki etkisinde etkileşimsel adaletin aracı rolünü } \\
\text { tespit etmeyi amaçlamaktadır. Araştırma verileri } \\
\text { Türkiye'de bir devlet üniversitesinde çalışan } 107 \\
\text { araştırma görevlisinden anket yönetim ile toplanmıştır. } \\
\text { Araştırma modelini test etmek için yapısal eşitlik modeli } \\
\text { (YEM) kullanılmıştır. Çalışmada ilk olarak mantar yönetim } \\
\text { tarzının örgütsel sinizm üzerindeki etkisi test edilmiştir. } \\
\text { Bu adımdan sonra aracı değişken araştırma modeline } \\
\text { dahil edilmiştir. Analizler sonucunda mantar yönetim } \\
\text { tarzının örgütsel sinizm alt boyutlarını (bilişsel, duyuşsal } \\
\text { ve davranışsal) pozitif, etkileşimsel adaletini negatif } \\
\text { yönde etkilediği sonucuna varılmıştır. Ancak mantar } \\
\text { yönetim tarzı ile örgütsel sinizm boyutları arasında } \\
\text { kurulan ilişkide etkileşimsel adaletin aracılık rolü } \\
\text { olmadığı sonucuna varılmıştır. }\end{array}$ & $\begin{array}{l}\text { The study aims to test the mediating role of interactional } \\
\text { justice on the effect of mushroom management style on } \\
\text { organizational cynicism. Data were collected by survey } \\
\text { method from } 107 \text { research assistants working in a state } \\
\text { university in Turkey. The structural equation model } \\
\text { (SEM) was used to test the research model. In the study, } \\
\text { firstly, the effect of mushroom management style on } \\
\text { organizational cynicism was tested. After this step, the } \\
\text { mediator variable was included in the research model. } \\
\text { As a result of the analysis, it was concluded that the } \\
\text { mushroom management style affected organizational } \\
\text { cynicism sub-dimensions (cognitive, affective, and } \\
\text { behavioral) positively, and affected interactional justice } \\
\text { negatively. However, it was concluded that interactional } \\
\text { justice does not have a mediating role in the relationship } \\
\text { between mushroom management style and } \\
\text { organizational cynicism dimensions. }\end{array}$ \\
\hline $\begin{array}{l}\text { Anahtar Kelimeler: Örgütsel Sinizm, Mantar Yönetim, } \\
\text { Etkileşimsel Adalet, Araştırma Görevlisi }\end{array}$ & $\begin{array}{l}\text { Keywords: } \quad \text { Organizational Cynicism, Mushroom } \\
\text { Management, Interactional Justice, Research Assistant }\end{array}$ \\
\hline JEL Kodları: D23, M10, M12 & D23, M10, M12 \\
\hline
\end{tabular}

\begin{tabular}{cl}
\hline \hline $\begin{array}{c}\text { Araştırma ve } \\
\text { Yayın Etiği } \\
\text { Beyanı }\end{array}$ & $\begin{array}{c}\text { Bu çalışma, 4.11.2020 tarih ve 01-11 sayılı Tokat Gaziosmanpaşa Üniversitesi Sosyal ve Beşerî Bilimler Araştırma ve } \\
\text { Etik Kurulu Karar Belgesi ile bilimsel araştırma ve yayın etiği kurallarına uygun olarak hazırlanmıştır. }\end{array}$ \\
$\begin{array}{c}\text { Yazarların } \\
\text { Makaleye } \\
\text { Olan Katkıları }\end{array}$ & Yazarlar makaleye eşit düzeyde katkı sağlamıştır (1. Yazar \%50- 2. Yazar \%50). \\
Çıkar Beyanı & Yazarlar açııından ya da üçüncü taraflar açısından çalışmadan kaynaklı çıkar çatışması bulunmamaktadır. \\
\hline \hline
\end{tabular}

\footnotetext{
${ }^{1}$ Dr. Öğr. Üyesi, Tokat Gaziosmanpaşa Üniversitesi, Sağlık Bilimleri Fakültesi, Acil Yardım ve Afet Yönetimi Bölümü, ahmet.mumcu@gop.edu.tr

2 Dr. Öğr. Üyesi, Tokat Gaziosmanpaşa Üniversitesi, Sağlık Bilimleri Fakültesi, Acil Yardım ve Afet Yönetimi Bölümü, mehtap.aras@gop.edu.tr
} 


\section{Introduction}

Leadership and management styles are effective in employee behavior in the organization. There can be no single factor affecting the behavior of employees in the organization. When we characterize the behavior as negative behavior, there may be more than one underlying factor. For example, poor or ineffective leadership leads to employee stress and negative effects on mental health (Kelloway, Sivanathan, Francis \& Barling, 2005: 90).

Mushroom management has recently emerged as a management style and entered management literature as a metaphor. Mushroom management is used to describe a management style in which employees (such as mushrooms) are kept in the dark and given some fertilizer periodically (Brown, Malveau, McCormick \& Mowbray, 1998: 147; Laplante \& Neill, 2006: 120). Mushroom management may be the source of some behavioral problems such as the occurrence of trust problems in employees, the decrease in organizational and work commitment, the emergence of burnout syndrome, the increase of cynicism, the increase of absenteeism, the increase in turnover rate, the formation of the intention to leave the job (Bolea \& Atwater, 2016: 119-120; Külekçi et al, 2020; Laplante \& Neill, 2006: 119; Tekin \& Birincioğlu, 2017: 29).

One of the behavioral problems in organizations is cynicism. Cynicism can be defined as negative feelings and behaviors in general. One of the factors affecting cynicism is the perception of justice, as perceptions of justice increase individuals' commitment to and trust in the organization (Chiaburu, Peng, Oh, Ganks \& Lomeli, 2013: 184; Dean et al., 1998). Although there is a difference between trust and cynicism, they are related concepts. Andersson\& Bateman (1997: 451) distinguished the relationship between cynicism and trust with the following statements, "whereas trust is a belief (or expectancy), cynicism is an attitude consisting of an affective component (negative feelings and disillusionment) as well as a belief (distrust)". Mushroom management, like cynicism, is closely related to the feeling of trust. There is a problem of trust in the managers of mushroom management due to the lack or absence of information sharing. In other words, the mushroom management style causes a loss of trust in employees towards their managers.

Interactional justice is about the belief a manager or leader is acting fairly. It is stated in the studies that interactional justice is closely related to trusting the leader (Bies, 2005; Wu, Huang, Li, \& Liu, 2011). Employees trust their managers or leaders when they think they are fair. With a leader who has adopted the mushroom management style, over time, employees lose their trust in their managers. It can be said that mushroom management is inversely proportional to interactional justice. That is, mushroom management destroys the interactional sense of justice. On the other hand, it is known that cynicism is closely related to the feeling of trust.

The effects of this management style on employees are not fully known due to the limited number of mushroom management articles. Laplante \& Neill (2006: 9) described communication, honesty, and leadership as management patterns of mushroom management. However, these definitions are theoretical, and applied studies have not been done in this area yet. Although there are a small number of applied studies in the Turkish literature. Mushroom management studies are limited by commitment (Tekin \& Birincioglu; 2017), motivation (Tekin \& Birincioglu, 2017), job stress (Külekçi et al., 2020), intention to quit (Külekçi et al., 2020), and job performance (Kâhya \& Ceylan, 2019). The concepts of cynicism, interactional justice, and mushroom management have common points. For example, the 
fairness of the leader, honesty, leadership, the presence of trust in the workplace or trust in the leader, participation in decisions can be listed as the common points of these three concepts. Based on these common points, it is possible to say that these three concepts can affect each other. We can say that in an organization where mushroom management is applied, employees' feelings of cynicism will increase, and their feelings of interactional justice will decrease significantly. Because trusting the leader or manager and establishing healthy communication with him increases motivation for the employees.

The study aims to reveal the mediating role of interactional justice in the relationship between mushroom management and cynicism by revealing the relationship between mushroom management and cynicism, and mushroom management and interactional justice. The results of the analysis revealed that there is a very strong relationship between mushroom management and cynicism. It has also emerged that there is a strong negative relationship between interactional justice and mushroom management, two concepts that affect trust in managers or leaders. Due to the limited number of studies on mushroom management, we think that these results contribute to the literature and will guide other studies on mushroom management.

\section{Theoretical Framework}

\subsection{Mushroom Management}

The concept of mushroom management, which is considered new in management literature and has not yet been fully framed. As can be understood from its name, this metaphor has been explained by analogy with the cultivation of mushrooms. It is a concept derived from the fact that fungi grow in the dark and dim light and therefore die when they get sunlight (Laplante \& Neill, 2006: 120). Fertilizers should also be given occasionally to ensure the growth and survival of the mushrooms (Brown et al. 1998: 147).

The most distinctive feature of this management style is the lack of information flow to the employees. The lack of information sharing is both its most distinctive feature and the source of the problems arising from this management style. Employees also have limited access to information, such as the occasional fertilization of mushrooms.

A working environment with no participation in decisions, the unilateral flow of information, and no feedback will have some effects and can cause some behavioral issues on employees. With a manager who has adopted a mushroom management style, employees may feel worthless and useless. Behavioral situations such as decreased organizational commitment, negative employee attitudes, increased cynicism, and burnout syndrome may occur in employees exposed to mushroom management style (Bolea \& Atwater, 2016: 119120).

There is also an insidious side to mushroom management. This management reflects a deeper problem of trust (Bolea \& Atwater, 2016: 119; Laplante \& Neill, 2006: 119). According to the results of a study conducted with 2000 employees in partnership with research firms Geckoboad and Censuswide (2015), one out of every four employees quit due to mushroom management. In this research, "79\% say they do not trust their managers who failed to share company data and more than \%90 say they would rather hear bad company news than being left in the dark" (Independent, 2015).

However, it may cause an increase in employee turnover rates. Studies have shown that mushroom management causes negative feelings and related behaviors in employees. Tekin 
\& Birincioglu (2017) have investigated the exposure to mushroom management style in research assistants. Research assistants stated that they were working under a mushroom management style and this situation had negative consequences for them. According to the results of the research, research assistants stated that their commitment to the organization and motivation decreased, and they had an intention to quit. Külekçi et al. (2020) concluded that mushroom management had a statistically significant effect on both job stress and intention to leave. In the studies of Kâhya \& Ceylan (2019), it was concluded that there was a positive increase in the working performance of mushroom management contrary to the negative effects in the literature.

\subsection{Organizational Cynicism}

Cynicism is a form of organizational behavior that includes negative feelings and behaviors. Andersson (1996: 1398) and Andersson \& Bateman (1997: 451) define cynicism as "is both a generalized and specific attitude involving frustration, hopelessness, disillusionment, and contempt toward and distrust of a person, group, or object(s)".

Cynicism is an issue that has been considered in different contexts. Our research concern is about organizational cynicism that employees' feelings toward leader and organization. Cynicism is the negative attitude of the employee towards the organization, and it expresses disdainful and critical behavior towards the organization, with the thought that the organization lacks integrity (Dean, Brandes, \& Dhwardkar, 1998: 345).

Some situations cause this behavior to occur. People do not suddenly behave in a negative, pessimistic, blaming, cynical, and accusatory manner for no apparent reason in the organization they work for (Dean et al. 1998; Reichers, Wanous \& Austin, 1997: 50). Organizational cynicism stems from employees' belief that there is no ethics, justice, sincerity, and honesty in the organization (Abraham, 2000: 269; Nafei \& Kaifi, 2013: 131). Cynical employees' feelings are humiliation, anger, distress, disgust, shame, resentment, and disillusionment to their organizations (Abraham, 2000: 269; Dean et al. 1998: 346; Stanley, Meyer, \& Topolnytsky, 2005: 456).

Some factors that lead to cynicism can be listed as not having a say in decision making (Bommer, Rich \& Rubin, 2005: 736), communication deficiencies, and power imbalances in the organization. The presence of organizational cynicism is also associated with some behavioral and attitudinal problems of employees. These are organizational commitment, employee's job satisfaction, job performance (Abraham, 2000; Chiaburu et al., 2013: 182; Reichers et al. 1997; Wanous, Reichers, \& Austin, 1994: 269), turnover (Tayfur et al., 2013), labor grievances, lack of organizational citizenship behaviors (Abraham, 2000; Andersson \& Bateman, 1997; Austin, 2004: 1423), interpersonal conflict, absenteeism (Andersson, 1996: 1400), intention to leave (Abugre, 2017).

Organizational cynicism has three dimensions: cognitive, behavioral, and emotional (affective) (Brandes \& Das, 2006: 237; Dean et al. 1998: 347; Stanley et al, 2005: 452). Dean et al. (1998: 345) explain these dimensions: "(1) a belief that the organization lacks integrity; (2) negative affect toward the organization; and (3) tendencies to disparaging and critical behaviors toward the organization that are consistent with these beliefs and affect." Also, Stanley et al (2005: 436) define cognitive cynicism "as disbelief of another's stated or implied motives for a decision or action". Emotional (affective) cynicism refers to the negative feelings the employee feels towards the organization. Negative feelings can be anger, 
distress, disgust, and even shame (Dean et al. 1998: 346). Behavioral cynicism refers to the negative behavior of employees due to the organization's lack of honesty and sincerity. Employees can reflect their cynical feelings as behavior (Dean et al. 1998: 346; Efeoğlu \& İplik, 2011: 349). They can also express these behaviors nonverbally, "such as "knowing" looks and rolled eyes, as well as the smirks and sneers by which cynics have long been recognized" (Brandes \& Das, 2006: 240; Dean et al. 1998: 346).

Organizational cynicism and organizational trust are interrelated concepts. It can be said that cynicism decreases or does not exist where there is organizational trust (Chiaburu et al. 2013: 183; Dean et al., 1998; Reichers et al., 1997).

Studies conducted so far on mushroom management style have revealed that mushroom management style decreases in organizational commitment, low motivation, decrease in trust in managers, and intention to quit. Since leadership styles directly affect employees 'emotions and behaviors, mushroom management style will also have an impact on some of the employees' emotions and behaviors. Studies have shown that it generally triggers negative emotions and behavior. The limited number of studies conducted does not fully reveal the effects of mushroom management on employees. The one-way flow of information, sharing a limited part of the information in the organization with employees, and lack of participation in decisions will result in a decrease in the employees' trust and sense of justice towards the organization and the manager. Cynicism is directly related to employees' sense of justice, and the lack of justice leads to cynicism in employees. Considering that honesty, trust, and justice are the factors that bring about cynicism, mushroom management can also cause cynicism. Based on this information, research hypotheses are as follows:

Hypothesis 1 (H1): Mushroom management style affects cynicism positively.

H1a: Mushroom management style affects cognitive cynicism positively.

H1b: Mushroom management style affects affective cynicism positively.

H1c: Mushroom management style affects behavioral cynicism positively.

\subsection{Interactional Justice}

Organizational justice refers to the perception of whether employees are treated fairly in the organization (Greenberg, 1988). The most common classification of organizational justice: distributive, procedural, and interactional (Bies, 2001: 93; Blodgett, Hill \& Tax, 1997: 186; Chiaburu et al., 2013: 184; Cropanzano \& Molina, 2015: 380).

Interactional justice is a strong predictor of subordinates' attitudes and behaviors (Li, Zhang, Zhang \& Zhou, 2017: 226). According to Bies (2001: 93), interactional justice is "the quality of interpersonal treatment they receive during the enactment of organizational procedures".

Interactional justice is the sense of justice arising from relationships between individuals and interpersonal treatment (Cropanzano, Prehar\& Chen, 2002: 326). The emotions people feel in these relationships determine interactional justice is existing or not. Studies on interactional justice have focused on respect, propriety, truthfulness, and justification (Colquitt, 2012) because interactional justice is about how employees are treated (respectful or rudely) during the conflict (Bies and Shapiro, 1987; Blodgett et al., 1997: 189; Cropanzano \& Molina, 2015: 381). When people think that they are treated with disrespect, they also think that they are being subjected to injustice (Bies, 2001: 104). 
Interactional justice separates into two parts, interpersonal fairness, and informational fairness. Interpersonal fairness is about the respect they receive from the other person, and informational fairness is about whether complete information is given when making decisions (Cropanzano, Stein \& Nadisic, 2011: 18, 30). Considering that there is little or no participation in decisions in the mushroom knowledge understanding and that the employees are given incomplete information; it can be said that those who work under this management style lack this sense of justice.

Interactional justice is a predictor of job performance and related to trust in the leader (Bies, 2005: 91- 92). It has been demonstrated that interactional justice mediates the relationship between benevolent leadership and trust in this leader (Wu et al, 2011). One of the most important elements of interactional justice is the leader and the leader's behavior. Leaders can earn employees' trust by being transparent in sharing information (Cartwright \& Holmes, 2006).

One of the biggest problems of mushroom management is the lack of trust in a leader. Li (2008: 427) stated that leaders have a very important role in creating trust in organizations and it will be easier to build trust through them. Trusting the leader also means thinking that the leader is fair. The leader's role is important for organizational justice (Pillai, Scandura, \& Williams, 1999: 765). Studies have revealed that trust in leaders mediates the relationship between interactional justice and employees' workplace behavior (Pillai et al.,1999; Aryee, Budhwar, \& Chen, 2002; Ertürk, 2007; Wu et al., 2011).

Leaders 'behavior has a direct impact on employees' emotions and behaviors. Employees have little trust in their leaders due to the lack of information sharing in mushroom management. Since trust affects the sense of justice, a mushroom management style can also directly affect interactional justice. Based on this information, hypothesis 2 was established as follows.

Hypothesis 2 (H2): Mushroom management style affects interactional justice negatively.

Employees' existing beliefs of interactional justice in the organization lead to a decrease in organizational cynicism so interactional justice is negatively related to feelings of organizational cynicism (Bernerth, Armenakis, Field \& Walker, 2007; Chiaburu et al., 2013: 184; Kwantes \& Bond, 2019; Shaharruddin, Ahmad \& Musa, 2016). There are multiple factors that can lead to cynicism. Lack of ethics, justice, and honesty leads to the emergence of cynicism and cynical feelings. On the other hand, interactional justice is a feeling that emerges when leaders do not both provide information flow to their employees and treat them with respect. Emotional and behavioral attitudes such as feeling insignificant, anger, anger, insecurity, and shame may develop over time in employees who are not respected by their leaders and whose information flow is not provided. Thus, we hypothesize:

Hypothesis 3 (H3): Interactional justice affects organizational cynicism negatively.

H3a: Interactional justice affects cognitive cynicism negatively.

$\mathrm{H} 3 \mathrm{~b}$ : Interactional justice affects affective cynicism negatively.

H3c: Interactional justice affects behavioral cynicism negatively.

There are many factors that affect the feelings, thoughts, and behaviors of employees in the workplace. The most important of these is the leader's behavior and leadership style. Trust in the leader and fair treatment of his employees make a difference in feelings and 
behaviors towards the leader. It is very normal for an employee to feel negative emotions if they do not trust their leader or manager and think they are unfair. Cynicism and trust are closely related. Studies have shown that an employee who does not trust his/her manager behaves cynically. When defining mushroom management, we mentioned that employees are kept in the dark. Keeping employees in the dark means giving them limited information, not being allowed to participate in decisions, and doing their jobs with limited information. And we stated that employees do not have a sense of trust towards the leader who adopts this management style. We have stated that trust is the common point of these three concepts. Therefore, the lack of trust in the leader or the manager, limited information to the employees, and lack of participation in decisions can lead to increased cynicism and lack of interactional justice in employees. Interactional justice is divided into two and one is informational justice. Informational justice is about whether complete information is given when making decisions (Cropanzano, Stein \& Nadisic, 2011: 18, 30). Therefore, a person working under a mushroom management style is expected to lack a sense of interactional justice. In other words, mushroom management negatively affects the interactional sense of justice. In line with these explanations, hypothesis 4 was developed:

Hypothesis 4 (H4): Interactional justice has a mediating role in the effect of mushroom management on organizational cynicism sub-dimensions (cognitive cynicism, affective cynicism, behavioral cynicism).

\section{Methodology}

General information about the method to be followed in the research and the design of the research are presented in Table 1 . The research data were obtained by using the online survey method within a thirty-day period in November 2020.

Table 1: Research Design

\begin{tabular}{ll} 
Research Type & Descriptor \\
Analysis of Research Technique & Deduction \\
Research Population & Research Assistants Working Actively in a State University \\
Sampling Method & Easy Sampling \\
Research Universe & 177 \\
Sample Size & 107 \\
Method of Measurement & Survey / 5-Point Likert Scale \\
Statistical Analysis Used & Structural Equation Model (SEM) \\
Statistical Programs Used & SPSS 22.0, AMOS 23.0 \\
\hline
\end{tabular}

\subsection{Purpose of the research}

This study aims to exhibit the mediating role of interaction justice in the effect of mushroom management on employees' perceptions of organizational cynicism. In line with this purpose, first, the effect of the mushroom management style on organizational cynicism will be determined. After this step, the mediating effect of the concept will be tested by including the interactional justice in the research model.

\subsection{Population and Sample}

Research assistants working at a state university constitute the universe of the study. There are many reasons for choosing research assistants in the study. It can be said that the first staff that can be expressed as subordinates of people in managerial positions in universities were research assistants. At state universities, research assistants are on the academic career ladder, which often constitutes the largest group of faculty members. 
Despite being the most crowded academic group, there are no representatives in the senate, faculty council, and faculty administrative council in the universities, who can be the voice of research assistants. This situation causes research assistants, who will become future faculty members, to stay away from the management process. Research assistants have a lack of participation in decisions and cannot access sufficient information. Often, research assistants are only expected to follow instructions given by academic managers. However, no disclosures are made regarding the decisions taken. In our country, in the academic community where the power distance is high, there may be deficiencies in information sharing due to the concern of power loss and insufficient communication can be established with research assistants. It is predicted that these expressions may affect the cynicism perception of research assistants against the administration and the justice relationship with the managers. Based on all these determinations, it is predicted that the organizational variables that we have constructed in the research will have a meaningful response within the causality relationship in the sample.

The research universe of the study consists of all research assistants working at a state university. From the data collection stage, research assistants who were assigned long-term assignments to other universities were excluded from the research universe. A total of 336 research assistants work actively in 17 faculties at the university, which constitutes the research universe. The survey was started by targeting the whole number. But due to pandemic conditions, 159 research assistants working in the faculty of medicine and training and research hospital under severe conditions could not be surveyed and were excluded from the research universe. Following the approval of the ethics committee, the survey link, ethics committee permission document, and explanation text were sent to the corporate e-mail addresses of research assistants in the research universe. At the end of a month, 107 surveys were returned. Findings regarding the demographic characteristics of the research assistants in the sample group are presented in Table 2.

Table 2: Distribution of the Demographic Characteristics of the Research Assistants in the Population

\begin{tabular}{cccccccc}
\hline & & $\mathrm{F}$ & $\%$ & & $\mathrm{~F}$ & $\%$ \\
\hline Gender & Male & 49 & 45,7 & Marital Status & Married & 61 & 57 \\
& Female & 58 & 54,3 & & Single & 46 & 43 \\
\hline Education & Graduate & 6 & 5,6 & & $23-30$ & 51 & 47,7 \\
& Master & 46 & 45,8 & Age(years) & $31-40$ & 56 & 52,3 \\
& PHD & 55 & 51,4 & & & \\
\hline Length of & $0-5$ & 55 & 51,4 & & & \\
\hline
\end{tabular}

As can be seen from Table 2, it is seen that the sample of the study has an almost homogeneous distribution in terms of demographic characteristics and the number of female research assistants in the sample group is more than men.

\subsection{Data Collection}

An online survey method was used to collect research data. The items in the survey were prepared according to the 5-point Likert type scale. In the study, open-ended and closedended survey was asked to determine the demographic characteristics (gender, marital status, education, age, and length of employment) of the research assistants. After this part, the scales of organizational variables were included in the survey. In the survey, the 
Mushroom Management Scale, Organizational Cynicism Scale, and Interactional Justice Dimension of the Organizational Justice Scale were used. In this part of the research, the general information about the scales in the survey, validity, and reliability analysis results are given, respectively.

Mushroom Management Scale: The mushroom management scale, was developed by Birincioğlu \& Tekin (2018) used to determine the perceptions of the employees on mushroom management. The scale consists of four dimensions and 19 items. These dimensions and number of items are inadequate information sharing (six items), the anxiety of power loss (five items), inadequate communication (four items), and lack of participatory management (four items). As a result of the explanatory and confirmatory factor analysis, reliability analysis tested by the researchers, it was reported that the scale was a valid and reliable measurement tool. Before starting the analysis of the scale in the study, the reverse-coded expressions were reversed. Then, secondary level confirmatory factor analysis was applied to the scale. As a result of the secondary level confirmatory factor analysis, two items from inadequate information sharing and one item from lack of participatory management were removed from the analysis. As a result of the analysis, it was determined that these items were not fully understood by the respondents, so the factor loadings of the statements did not reach a sufficient level. As a result of the confirmatory factor analysis, it was determined that the index values of the four-factor structure of the scale have good fit values. The goodness of fit index values for the confirmatory factor analysis were determined at the ( $p$ $<0.01)$ significance level as (x2/df: 1.543, RMSEA: 0.072, NFI: 0.902, CFI: 0.962, GFI: 0.861). After the validity analysis, the scale and its sub-dimensions were subjected to reliability analysis. Cronbach's alpha internal coefficients of consistency of the scale and its subdimensions were determined as Inadequate Information Sharing: 0.848, Anxiety of Power Loss: 0.925, Inadequate Communication: 0.851, Lack of Participatory Management: 0.837.

Interactional Justice Scale: Interactional justice is a dimension of organizational justice. The organizational justice scale developed by Niehoff \& Moorman (1993) was used in the study to measure interactional justice. In the organizational justice scale, there are 9 items for the measurement of the interactional justice dimension. As a result of the research conducted by Gürbüz \& Mert (2009), it was reported that the scale is a valid and reliable measurement tool for organizational justice measurements in our country. Confirmatory factor analysis was subjected to determine the construct validity of the interactional justice scale. As a result of the confirmatory factor analysis, it was determined that the goodness of fitness index values of the single-factor structure of the scale have good fit values. The goodness of fit index values for the confirmatory factor analysis were determined at the $(p$ $<0.01)$ significance level as (x2 / df: 1.659 RMSEA: 0.079, NFI: 0.973, CFI: 0.989, GFI: 0.919). As a result of the reliability analysis, the Cronbach's alpha internal coefficient of consistency for the interactional justice was determined as 0.981 .

Organizational Cynicism Scale: Organizational cynicism was tested by Brandes, Dharwadker \& Dean's (1999) scale. This scale is a revised version of the 14-items organizational cynicism scale developed by Brandes (1997). The organizational cynicism scale consists of three dimensions. These sub-dimensions and number of items are cognitive cynicism (five items), effective cynicism (four items), behavioral cynicism (four items). The scale is accepted as a measurement tool that is frequently used in cynicism studies. As a result of their validation study, Karacaoğlu \& Ince (2012) reached findings indicating that the scale is 
a powerful and sufficient measurement tool in the Turkish samples. In this study, confirmatory factor analysis was performed to test the construct validity of the organizational cynicism scale. As a result of the confirmatory factor analysis made based on the primary level multi-factor model measurement, it was determined that the scale was distributed by the three-factor structure existing in its original structure. The goodness of fit index values for the confirmatory factor analysis were determined at the $(p<0.01)$ significance level as $x 2 / d f$ : 1.644, RMSEA: 0,078, NFI: 0,955, CFI: 0,982, GFI: 0,887. The Cronbach's alpha internal coefficient of consistency of dimensions was determined as Cognitive Cynicism: 0.931, Affective Cynicism: 0.985, Behavioral Cynicism: 0.965.

\subsection{Research Model}

In the study, after determining the validity as a result of the confirmatory factor analysis, mushroom management was constructed in the research model at the general dimension level and as a latent variable through secondary level factors. This situation prevents confusion in the research model and ensures that the study has a simple and understandable research model. The dimensions of interactional justice and organizational cynicism subdimensions are constructed in the model as observed variables. Also, organizational cynicism is included in the research model at the dimension level. As the dependent variable of the research, it enables the determination of the effects on the dimensions of organizational cynicism separately. The research model is shown in Figure 1.

Figure 1: Research Model

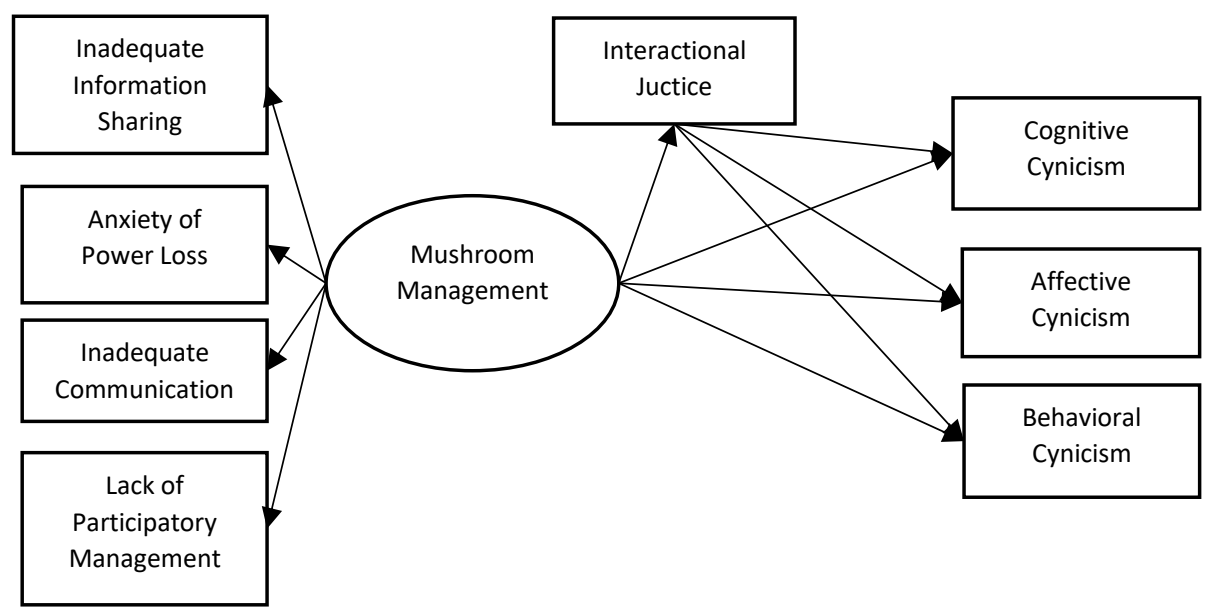

\section{Findings}

In the study, before testing the structural equation model, the relationships between the organizational variables in the research model were analyzed. Following, correlation analysis was carried out to determine the relationships between the mushroom management style, interactional justice, cognitive cynicism, affective cynicism, and behavioral cynicism. Statistical values for correlation analysis are shown in Table 3. 
Table 3: Correlation Analysis of Research Variables

\begin{tabular}{llllll}
\hline & 1 & 2 & 3 & 4 & 5 \\
\hline 1.Mushroom Management & 1 & & & \\
\hline 2.Interactional Justice &,$- 823^{*}$ & 1 & & & \\
\hline 3.Cognitive Cynicism &, $773^{*}$ &,$- 699^{*}$ & 1 &, $735^{*}$ & 1 \\
\hline 4.Affective Cynicism &, $723^{*}$ &,$- 642^{*}$ &, $664^{*}$ &, $699 *$ & 1 \\
\hline 5. Behavioral Cynicism &, $536^{*}$ &,$- 512^{*}$ & & \\
\hline$*$ p<0,01 & & & & \\
\hline
\end{tabular}

When we look at the data obtained from Table 3, it is seen that mushroom management has a negative significant relationship with interactional justice $(r:-, 823)$. And mushroom management has positive significant relationships which are value range ( $r: 536$ and $r$ : 773) with the dimensions of organizational cynicism. It is seen that there are significant negative relationships in the value range $(r:-, 512$, and $r:-, 699)$ between the dimensions of organizational cynicism and interactional justice.

In the study, the structural equation model was applied to test the research model and the mediation effect. The reason for using the structural equation model in mediation analysis is that the model offers a stronger infrastructure by including measurement and residual errors in the analysis (Meydan \& Şeşen, 2011). Baron\&Kenny (1986) state that the first condition of mediation effect is a significant relationship to be established between dependent and independent variables. Accordingly, before testing the research model, the effect of mushroom management, which is the independent variable of the model, on the dimensions of organizational cynicism, which is the dependent variable, was tested through the structural equation model. As a result of the established structural equation model, it was determined that the model has good fit values (x2 / df: 1.077; RMSEA: 0.027; NFI: ,982; CFI: 989; GFI: ,973) at the ( $p<0.001)$ significance level. According to analysis findings, it was found that mushroom management has a significant effect of 0.82 on cognitive cynicism, 0.75 on affective cynicism, 0.56 on behavioral cynicism.

After this step, interactional justice, which is the mediator variable, was included in the model. The research model shown in Figure 2 was tested through the structural equation model. First, three modifications were made that increased the goodness of fit values of the model and were theoretically significant. Afterward, the research model (final model) that shows meaningful paths was created as a result of extracting meaningless ways one by one from the model and repeated analysis. This model is shown in Figure 2. 
Figure 2: Research Model (Final Model)

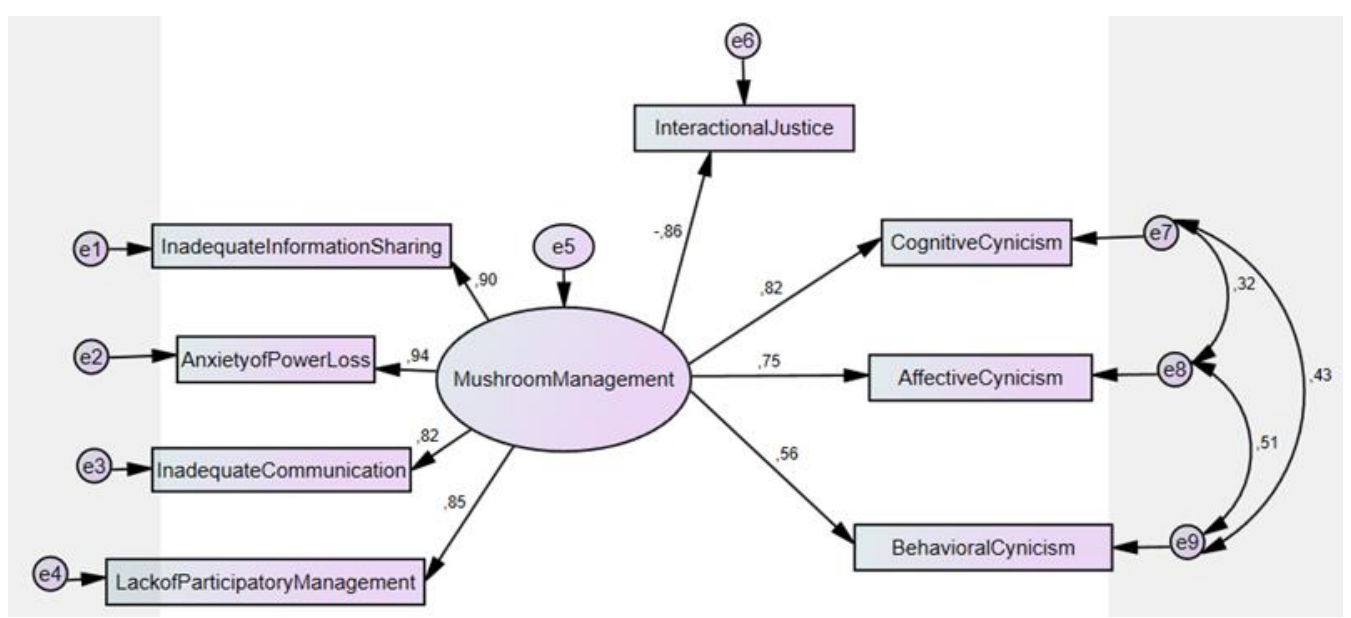

It was determined that the final model of the study had good fit values ( $x 2$ / df: 1.063; RMSEA: 0.24; NFI: 0.977; CFI: 0.997; GFI: 0.964) at the significance level ( $p<0.001)$. As can be seen in Figure 2, all paths from interactional justice to cognitive cynicism, affective cynicism, and behavioral cynicism were found to be meaningless at $(p<0.05)$ significance level. Apart from this, it was determined that all the paths in the model were significant at $(p<0.001)$ significance level. Standardized regression weights and $(p)$ values of significant paths in the research model are presented in Table 4.

Table 4: Standardized Regression Weights of the Paths on the Research Model

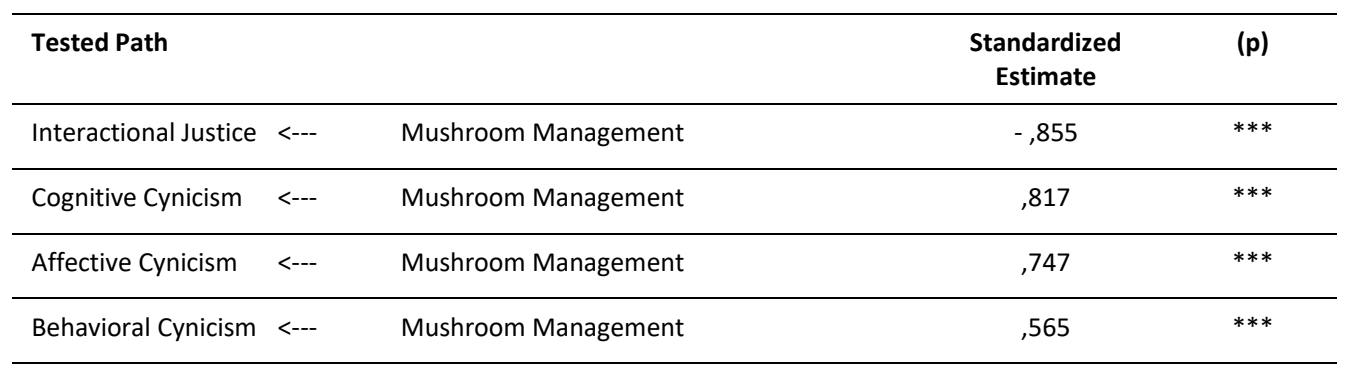

$* * * p<0,001$

\section{Discussion and Conclusion}

Considering the findings obtained from the data of the study, it was determined that the mushroom management style has positive and significant effects on the cognitive cynicism, affective cynicism, and behavioral cynicism perception of the research assistants. $\mathrm{H} 1 \mathrm{a}, \mathrm{H} 1 \mathrm{~b}$, and $\mathrm{H} 1 \mathrm{c}$ were supported. In this case, it has been determined that the mushroom management style applied to research assistants who will qualify as future faculty members increase their perception of cynicism, which is a negative attitude towards their institution rather than increasing their performance. The basis of cynicism is that the person has negative feelings and does not trust the institution they work for. Cynicism has been accepted as a general attitude that includes insecurity that people are trustworthy and sincere. The 
cynical individuals are defined as those who approach even the most innocent and wellintentioned human behaviors skeptically and critically (Andersson \& Bateman, 1997: 450; Vardi \& Weitz, 2004: 133).

In this respect, the mushroom management style's sub-dimensions as a lack of participatory management, inadequate communication, and inadequate information sharing can increase the negative feelings, feelings of trust, and skepticism of the employees. When we look at the relationship between concepts in our research sample, if there is insufficient communication with a research assistant with a doctoral or master education level, sufficient information is not shared with the concern of loss of power, and the opportunity to participate in the management is not given, the employee's negative behavior pattern towards the institution can be predicted as an expected result.

As a result of the analysis, it was determined that the mushroom management style has a significant negative effect on interactional justice. $\mathrm{H} 2$ was supported. In the fairness of interactional, the employee expects the manager to exchange views on the consequences and effects of a business decision. Also, employees expect justifiable reasons and reasonable and logical explanations to be made clear to them in the decisions taken in the workplace. If mushroom management style is dominating an organization, it can be accepted as an inevitable result that the interactional justice, which measures the quality of the attitudes and behaviors the employee is exposed to during the implementation of organizational operations, is negatively affected by this management style. Research results also support this.

In the research model, all the paths from interactional justice to organizational cynicism dimensions were found to be meaningless. In other words, the significant effect of the mediator variable, on the dependent variable could not be determined. According to this situation, one of the conditions of the mediation effect that Baron and Kenny (1986) put forward could not be provided.

Based on this result, interactional justice has no mediating role on the effect of the mushroom management style on organizational cynicism's sub-dimensions. H3 was not supported. There are many studies on the negative effect of interactional justice on organizational cynicism (Bernerth et al, 2007; Chiaburu et al., 2013: 184; Kwantes \& Bond, 2019; Shaharruddin et al, 2016). At this point, our research results differ from the literature. In the analyzes performed outside the research model, it was determined that the model established between the dimensions of interactional justice and organizational cynicism has significant positive effects. This situation shows that the effect of the mushroom management style in the research model on the dimensions of organizational cynicism and interactional justice makes the paths between the interactional justice and organizational cynicism's subdimensions meaningless.

On the other hand, it has been determined that the mushroom management style has a negative effect on the personnel's perception of interactional justice. As a result of empirical studies, it has been revealed that both interactional injustice and cynicism have many negative effects on the attitudes and behaviors of employees in organizations (Abraham, 2000; Abugre, 2017; Andersson \& Bateman, 1997; Austin, 2004, Bernerth et al, 2007; Chiaburu et al., 2013; Kwantes \& Bond, 2019; Shaharruddin et al, 2016; Shahzad \& Mahmood, 2012; Tayfur et al., 2013). In this context, various suggestions for researchers and academic unit managers are presented based on the research findings in the study. 
Unlike other academics, research assistants do not have a say in participating in management decisions. In the university, the research assistants' representative council should be established, and a representative should be appointed to this council, which can enable the research assistants to convey their problems, opinions, and thoughts to the managers or administrative bodies of the relevant unit.

A participatory management approach should be adopted in academic units and a participatory management style should be applied to research assistants. Research assistant representatives should be able to attend academic or administrative meetings held in various units of universities to speak particularly on issues concerning research assistants and present their opinions. As academic personal with a doctorate education, they should be able to take authority and responsibility in various units of universities.

The principles of transparency, clarity, and good governance should be conformed in sharing information. Academic unit managers should provide research assistants with the opportunity to reach whenever they needed. Managers should adopt a more effective and democratic two-way communication style instead of adopting a one-way communication process in their relations.

Academic unit managers should not see their knowledge as a source of power over research assistants and should not use this information as a means of authority. Regular meetings should be held with research assistants at the university and information sharing should be avoided as academic personnel of the institution. Especially administrators should give information about every subject that concerns research assistants.

\subsection{Limitations and Future Research}

The number of research conducted in the field of mushroom management, which is a new concept in the field of organizational behavior, is limited. At this point, increasing the number of studies and the diversity of the sample group will allow us to identify the antecedents and consequences of the mushroom management style. The literature states that mushroom management is an important management style for employees to perform successfully. However, studies show that research samples consist of blue-collar workers (Kahya \& Ceylan, 2019; Külekci et al., 2020) Based on our research results, it is not possible to say that this situation will occur for white-collar employees. In this respect, comparing blue and whitecollar employees in an enterprise operating in the private sector will enable to reveal the context in which the concept should be handled. The study has limitations. The research was applied to research assistants working in a state university due to time and place constraints. For this reason, the research results cannot be generalized. This situation is the main limitation of the study. Future research can be applied to employees operating in different sectors. As a result of the data obtained, the results of various occupational groups can be evaluated by comparing the sectors. 


\section{References}

Abraham, R. (2000), "Organizational Cynicism: Bases and Consequences", Genetic Social and General Psychology Monographs, Vol. 126, No. 3: 269-92.

Abugre, J.B. (2017), "Relations at Workplace, Cynicism, and Intention to Leave: A Proposed Conceptual Framework for Organisations", International Journal of Organizational Analysis, Vol. 25, No.2: 198-216.

Andersson, L.M. (1996), "Employee Cynicism: An Examination Using a Contract Violation Framework". Human Relations, Vol. 49, No.11: 1395-1418.

Andersson, L.M.; Bateman, T. S. (1997), "Cynicism in the Workplace: Some Causes and Effects", Journal of Organizational Behavior, Vol.18, No.5: 449-469.

Aryee, S.; Budhwar, P. S.; Chen, Z. X. (2002), "Trust as A Mediator of the Relationship Between Organizational Justice and Work Outcomes: Test of A Social Exchange Model", Journal of Organizational Behavior, Vol.23, No.3: 267-285.

Austin, J.T. (2004), "Cynicism About Organizational Change: An Attribution Process Perspective", Psychological Reports. Vol.94: 1421-1434.

Baron, R. M.; Kenny, D. A. (1986), "The Moderator-Mediator Variable Distinction in Social Psychological Research: Conceptual, Strategic, And Statistical Considerations" Journal of Personality and Social Psychology, Vol. 51, No.6: 1173-1182

Bernerth, J.B.; Armenakis, A.A.; Feild, H.; Walker, H. (2007), "Justice, Cynicism, and Commitment A Study of Important Organizational Change Variables", The Journal of Applied Behavioral Science, Vol.43, No.3:303-326.

Bies, R.J., (2001), "Interactional (In)Justice: The Sacred and the Profane", Advances in Organizational Justice, (Eds. J. Greenberg; R. Cropanzano), Stanford University Press, Stanford: 89-118.

Bies, R. J. (2005), “Are Procedural Justice and Interactional Justice Conceptually Distinct?", Handbook of Organizational Justice, (Eds. J. Greenberg; J. A. Colquitt), Mahwah, NJ: Erlbaum: 85-112.

Bies, R.J.; D.L. Shapiro (1987), "Interactional Fairness Judgements: The Influence of Causal Accounts", Social Justice Research, Vol.1, No.2:199-218.

Birincioğlu, N.; Tekin, E. (2018), “Mantar Yönetim Ölçeği Geliştirilmesi Üzerine Bir Çalışma”, Business and Economics Research Journal, C. 9, S.1:169-185.

Blodgett, J.G.; Hill, D.J.; Tax S.S. (1997), "The Effects of Distributive, Procedural, and Interactional Justice on Post Complaint Behavior", Journal of Retailing, Vol.73, No.2:185-210.

Bloea, A.; Atwater, L. (2016), Applied Leadership Development: Nine Elements of Leadership Mastery. New York: Taylor \& Francis Group.

Bommer, W. H.; Rich, G. A.; Rubin, R. S. (2005), “Changing Attitudes About Change: Longitudinal Effects of Transformational Leadership Behavior on Employee Cynicism About Organizational Change", Journal of Organizational Behavior, Vol. 26, No.7:733-753.

Brandes, P. M. (1997), Organizational Cynicism: Its Nature, Antecedents, and Consequences. (Unpublished Ph.D. Thesis), University of Cincinnati.

Brandes, P. M.; Dharwadkar, R.; Dean, J. W. (1999), "Does Organizational Cynicism Matter? Employee and Supervisor Perspectives on Work Outcomes", Eastern Academy of Management Proceedings: 150-153.

Brandes, P.; Das, D. (2006), "Locating Behavioral Cynicism at Work: Construct Issues and Performance Implications", Employee Health, Coping and Methodologies (Research in Occupational Stress and Well Being, Vol. 5), (Ed. Perrewé, P.L.; Ganster, D.C.), Emerald Group Publishing Limited, Bingley: 233-266. 
Brown, W. H.; Malveau, R. C.; McCormick, H. W.; Mowbray, T. J. (1998), Antipatterns: Refactoring Software, Architectures, And Projects in Crisis. Canada: John Wiley \& Sons, Inc.

Cartwright, S.; Holmas, N. (2006), "The Meaning of Work: The Challenge of Regaining Employee Engagement and Reducing Cynicism”, Human Resource Management Review, Vol.16, No.2:199-208.

Chiaburu, D. S.; Peng, A. C.; Oh, I.; Ganks, G. C.; Lomeli, L. C. (2013), "Antecedents and Consequences of Employee Organizational Cynicism: A Meta-Analysis", Journal of Vocational Behavior, Vol.83, No.2: 181-197.

Cropanzano, R.; Prehar, C.; Chen, P. (2002). “Using Social Exchange Theory to Distinguish Procedural from Interactional Justice", Group \& Organization Management. Vol. 27, No.3:324-351.

Cropanzano, R.; Stein, J. H.; Nadisic, T. (2011), Social Justice and The Experience of Emotion, New York: Routledge.

Colquitt, J.A. (2012), "Organizational Justice", The Oxford Handbook of Organizational Psychology, (Ed. W. J. Kozlowski), Oxford University Press, New York: 526-547.

Cropanzano, R.; Molina, A. (2015), "Organizational Justice”. International Encyclopedia of the Social \& Behavioral Sciences 2nd ed., (Ed. J. D. Wright), Elsevier, Oxford:379-384.

Dean, J.W.; Brandes P.; Dharwadkar R. (1998), "Organizational Cynicism", The Academy of Management Review, Vol.23, No.2:341-352.

Efeoğlu, I.E.; İplik, E. (2011), “Algılanan Örgütsel Adaletin Örgütsel Sinizm Üzerindeki Etkilerini Belirlemeye Yönelik İlaç Sektöründe Bir Uygulama”, Ç.Ü. Sosyal Bilimler Enstitüsü Dergisi, C.20, S.3: 343360.

Ertürk, A. (2007), "Increasing Organizational Citizenship Behaviors of Turkish Academicians: Mediating Role of Trust in Supervisor on the Relationship Between Organizational Justice and Citizenship Behaviors", Journal of Managerial Psychology, C.22, S.3:257-270.

Greenberg, J. (1988). "Cultivating an Image of Justices: Looking Fair on The Job", The Academy of Management Executive, Vol.2, No.2: 155-158.

Gürbüz, S.; Mert, i. S. (2009), "Örgütsel Adalet Ölçeğinin Geçerlilik ve Güvenilirlik Uygulaması", Amme İdaresi Dergisi, C.42, S.3:117-139.

Karacaoğlu, K.; İnce, F. (2012), “Brandes, Dharwadkar ve Dean'in (1999) Örgütsel Sinizm Ölçeği Türkçe Formunun Geçerlilik ve Güvenilirlik Çalışması: Kayseri Organize Sanayi Bölgesi Örneği”, Business and Economics Research Journal, C.3, S.3:77-92.

Kâhya, V.; Ceylan, E. (2019), "İ̧̧ Performansını Artırmada Yeni Bir Yaklaşım: Mantar Yönetim". Uluslararası Sosyal ve Beşerî Bilimler Araştırma Dergisi. C.6, S.45:3773-3781.

Kelloway, E.; Sivanathan, K.; Francis, N.; Barling, L. (2005), "Poor leadership", Handbook of Work Stress, (Eds. J. Barling; E. K. Kelloway; M. Frone), Thousand Oaks: Sage.

Külekçi, M.K.; Özbozkurt, O. B.; Bahar, E. (2020), "The Mediating Role of Mushroom Management Within the Impact of Job Stress on Intention to Leave", İşletme Araştırmaları Dergisi, C. 12, S.1:361-371.

Kwantesa, C.T.; Bondb, M. H. (2019), “Organizational Justice and Autonomy as Moderators of the Relationship Between Social and Organizational Cynicism", Personality and Individual Differences Vol. 151:1-10

Laplante, P. A.; Neill, C. J. (2006), Antipatterns: Identification, Refactoring, and Management, Boca Raton: Taylor \& Francis Group.

Li, P. P. (2008), "Toward A Geocentric Framework of Trust: An Application to Organizational Trust", Management and Organization Review, Vol.4, No.3:413-439.

Meydan, C. H.; Şeşen, H. (2011), Yapısal Eşitlik Modellemesi AMOS Uygulamaları, Ankara: Detay Yayıncılık. 
Nafei, W.A.; Kaifi, B. A. (2013), "The Impact of Organizational Cynicism on Organizational Commitment: An Applied Study on Teaching Hospitals in Egypt". European Journal of Business and Management, Vol.5, No.12:131-147.

Niehoff, B. N.; Moorman, R. (1993), "Justice as a Mediator of Relationship Between Methods of Monitoring and Organizational Citizenship Behavior", Academy of Management Journal, Vol.36, No.3:527-556

Pillai, R.; Scandura, T. A.; Williams, E. A. (1999), "Leadership and Organizational Justice: Similarities and Differences Across Cultures", Journal of International Business Studies, Vol. 30, No.4:763-779.

Reichers, A.; Wanous, J.; Austin, J. (1997), "Understanding and Managing Cynicism About Organizational Change", Academy of Management Executive, Vol.11, No.1:48-59.

Shahzad, A.; Mahmood, Z. (2012), "The Mediating-Moderating Model of Organizational Cynicism and Workplace Deviant Behavior: Evidence from Banking Sector in Pakistan". Middle-East Journal of Scientific Research, Vol. 12, No.5:580-588.

Shaharruddin, S.; Ahmad, F.; Musa, M.M. (2016), "Cynicism in Organizations: Does Organizational Justice Matter?" International Journal of Research in Business Studies and Management, Vol.3, No.2:4960.

Stanley, D. J.; Meyer, J. P.; Topolnytsky, L. (2005), "Employee Cynicism and Resistance to Organizational Change", Journal of Business and Psychology, Vol.19, No.4:429-459.

Tayfur, O.; B. Karapinar, P. M.; Camgöz, S. (2013). "The Mediating Effects of Emotional Exhaustion Cynicism and Learned Helplessness on Organizational Justice Turnover Intentions Linkage", International Journal of Stress Management, C. 20, S.3:193-221.

Tekin, E.; Birincioğlu, N. (2017), "Bilgi Çağının Odak Noktası Üniversitelerde Mantar Yönetimi”, International Journal of Academic Value Studies, C.3. S.14: 22-29.

Vardi, Y.; Weitz, E. (2004), Misbehavior in Organizations: Theory, Research, and Management. New Jersey: Lawrence Erlbaum Associates.

Wanous, J. P.; Reichers, A. E.; Austin, J. T. (1994), "Organizational Cynicism: An Initial Study", Academy of Management Best Papers Proceedings: 269-273.

Wu, M.; Huang, X.; Li, C.; \& Liu, W. (2011), "Perceived Interactional Justice and Trust in Supervisor as Mediators for Paternalistic Leadership", Management and Organization Review, Vol.8, No.1:97-121.

Independent (2015). https://www.independent.co.uk/news/business/news/britain-s-workforcefacing-mushroom-management-approach-resulting-employees-quitting-says-report-a6672296.html., (Access: 09.11.2020).

https://www.geckoboard.com/blog/research-report-one-in-four-employees-leave-due-tomushroom-management/, (Access: 09.11.2020). 